\title{
Prison Theatre and an Embodied Aesthetics of Liberation: Exploring the Potentials and Limits
}

\author{
Sarah Woodland
}

check for updates

Citation: Woodland, Sarah. 2021. Prison Theatre and an Embodied Aesthetics of Liberation: Exploring the Potentials and Limits. Humanities 10: 101. https://doi.org/10.3390/ h10030101

Received: 28 June 2021

Accepted: 6 September 2021

Published: 9 September 2021

Publisher's Note: MDPI stays neutral with regard to jurisdictional claims in published maps and institutional affiliations.

Copyright: (C) 2021 by the author. Licensee MDPI, Basel, Switzerland. This article is an open access article distributed under the terms and conditions of the Creative Commons Attribution (CC BY) license (https:// creativecommons.org/licenses/by/ $4.0 /)$.
Faculty of Fine Arts and Music, University of Melbourne, Melbourne 3010, Australia; sarah.woodland@unimelb.edu.au

\begin{abstract}
Prison theatre practitioners and scholars often describe the sense of imaginative freedom or "escape" that theatre and drama can facilitate for incarcerated actors, in contrast to the strict regimes of the institution. Despite this, the concept of freedom or liberation is rarely interrogated, being presented instead as a given - a natural by-product of creative practice. Drawing from John Dewey's (1934) pragmatist aesthetics and the liberatory pedagogies of Bell Hooks (2000) and Paulo Freire (1996), I propose an embodied aesthetics of liberation in prison theatre that adds depth and complexity to claims for freedom through creativity. Reflecting on over twenty years of prison theatre practice and research, I propose that the initial "acts of escape" performed through engaging the imagination are merely the first threshold toward more meaningful forms of freedom. I frame these as the following three intersecting domains: "Acts of unbinding", which represents the personal liberation afforded by experiences with theatre in prison; "acts of love", which expresses how the theatre ensemble might represent a "beloved community" (hooks); and "acts of liberation", which articulates how these experiences of self-and-world creation may ripple out to impact audiences and communities. An aesthetics of liberation in prison theatre can, therefore, be conceived as an embodied movement towards personal and social renewal; an approach that deepens our understanding of its oft-cited humanising potential, and its limits.
\end{abstract}

Keywords: theatre studies; prison theatre; applied theatre; applied drama; aesthetics; pragmatist aesthetics; somaesthetics; liberatory pedagogy

\section{Introduction}

Theatre has likely been performed in prisons and other sites of incarceration for centuries, with documented examples ranging from the 1789 convict staging of George Farquhar's The Recruiting Officer in Australia, to theatre and art occurring in prison and internment camps in the Second World War, to Herbert Blau's famous 1957 staging of Beckett's Waiting for Godot in San Quentin Prison (see Balfour 2004; McAvinchey 2011). The act of mounting a performance or theatrical event inside a prison captures the imagination as a powerful juxtaposition between the deprivations of the institution and the joyous celebration of art and life-a triumph of the human spirit against adversity. Correctional institutions globally have incorporated theatre and performance within their recreational, educational and rehabilitative programming, recognising the potential for such activities to develop practical skills and competencies such as communication, teamwork and literacy. In some cases, prison theatre groups or companies have been formed from within, operating autonomously with limited external support or input.

The impacts of these programs are often interrogated from a criminological perspective, investigating how they might contribute to desistance from crime and reduced recidivism (Davey et al. 2015). Over the past twenty-five years, the practice and scholarship of "prison theatre" has also emerged as an important sub-discipline within theatre studies, often situated within applied theatre, where prison-based performances are interrogated for their social impacts, performative qualities and political implications (Thompson 1998; Balfour 2004; Shailor 2011). 
Prison theatre programs can range from drama-based workshop processes that approach behaviour and attitudes through a therapeutic lens (see Baim et al. 2002); to group devised performances that explore the lives and stories of incarcerated performers through theatre, dance and song (see Clark 2020); to performances from the Western canon-from Euripides to Shakespeare to Beckett (see Pensalfini 2016). These programs are often led by practitioners who emphasise social justice orientations, liberatory pedagogies or radical political positionalities (see Billone 2009; Heritage 2006). This engenders a tension between the ideals underpinning the programs and their potential to uphold systems of oppression. Scholars such as James Thompson (1998) and Aylwyn Walsh (2019) have adopted a consistently critical stance in addressing this tension. Walsh writes, "Since radical practice would seek to dis-articulate power structures, the demands of sanctioned entry into a secure institution invites complicity with its narratives" (p. 82).

Nevertheless, there is a strong focus in much prison theatre practice and scholarship on the "humanising" potential of the work, with limited interrogation of what this means and how it is achieved; and the field is replete with references to freedom. Specifically, researchers and practitioners often describe the sense of creative or imaginative freedom that theatre and drama can offer in contrast to the strict regimes of the institution (see Shailor 2011). Despite this, the concept of freedom or liberation in this context is rarely interrogated, being presented instead as a given-a natural by-product of creative practice. In her recent investigation into prison theatre globally, Ashley Lucas (2020) expresses her unease with this, wishing to draw a distinction between theatre as liberatory in a personal sense, and its capacity to bring about actual liberation from the prison itself: "Theatre can promote free thinking and empathy, but it is not, in fact, liberation" (p. 39). For me, Lucas's statement represents a compelling provocation, prompting me to place assumptions of freedom or liberation in prison theatre under closer scrutiny.

Over the past twenty years, I have facilitated drama, theatre and performance programs in prisons in Australia, New Zealand and the United Kingdom. I have also witnessed prison-based performances and theatre workshops and spoken with many participants and practitioners about the work. My practice has incorporated aspects of community-based theatre, Theatre of the Oppressed (Boal 1985), theatre and drama in education, testimonial theatre and, more recently, audio drama and soundscape - all of which can largely be gathered under the "umbrella term" of applied theatre (Prendergast and Saxton 2009). While it is beyond the scope of this paper to fully unpack this often-contentious term, it broadly relates to theatre and drama practices that are undertaken in non-traditional theatre spaces and are directed toward a transformative social purpose.

The applied theatre field has been heavily influenced by the liberatory pedagogy first introduced by Paulo Freire (1996), and subsequently adapted to the theatre (and to drama and theatre in education) by influential practitioners such as Augusto Boal (1985), Dorothy Heathcote (Wagner 1976) and John O'Toole (1992). Influenced also by the Marxist Epic Theatre of Bertolt Brecht and the feminist and socialist strains of the 1960s' counter-culture movement, these practitioners deposed the role of the omnipotent theatre director and sought to empower audiences and learners to have agency in a process of transformative meaning making through the artform. The goal was to liberate minds and bodies from the oppressive structures and power dynamics that existed in traditional theatres, schoolrooms and in the wider community.

Throughout my practice and research in prison theatre, I have seen first-hand the complexities and tensions that arise when attempting to enact an anti-oppressive, artsbased, liberatory pedagogy inside a coercive institution. "Freedom" is a loaded term, which is highly conditional, working as it does in direct contravention of the institution's purpose. Ideals of liberation in prison theatre are further conditioned by the state-sponsored systems of oppression that exist beyond the physical architecture of the prison, operating as "carceral webs" (Anthony 2020) that continue to entrap marginalised populations in intergenerational cycles of punishment, disadvantage and dependency. Nevertheless, I believe it is possible to articulate an aesthetics of liberation at work in prison theatre- 
one that encompasses the personal and the political and serves to bring some nuance to discussions of the humanising potential of the arts in prisons.

This paper begins by outlining a pragmatist aesthetic frame that builds on the aesthetic theory of John Dewey (1934), and subsequent scholars such as Richard Shusterman (2008) and Mark Johnson (2007), who have extended on Dewey's original project to centre ideas of embodiment in aesthetic experience. I also outline how this aesthetic frame has some important alignments to the liberatory pedagogy and politics of Paulo Freire (1996) and bell hooks (2000) that inform my approach. What follows is a philosophical reflection on how an embodied aesthetics of liberation might be conceived, drawing from a number of programs and projects in which I have been directly involved over the past two decades.

My reflection first introduces and draws together common themes of pragmatist aesthetics and the pedagogies and politics of liberation, before moving into a brief overview of how they might be deployed in prison theatre, with particular reference to the projects I have been involved in. From there, I introduce the notion of "escape" in prison theatre as signifying the kind of imaginative freedom to which Lucas $(2020$, p. 39) alludes and which, in and of itself, does not constitute liberation. I contend, however, that we can go much deeper in examining notions of liberation in prison theatre. To that end, I go on to identify the following three intersecting domains within which an embodied aesthetics of liberation might be conceived in prison theatre: Acts of Unbinding, which explores the personal liberation afforded by experiences with theatre in prison; Acts of Love, which draws on hooks' (2000) liberatory politics to explore how the theatre ensemble might represent a "beloved community;" and Acts of Liberation, which articulates how these experiences of self-and-world creation may ripple out towards audiences and communities. I conclude with a hopeful suggestion that this approach might work towards transforming systems of mass incarceration. Drawing from pragmatist aesthetics and liberatory pedagogies and politics I seek to demonstrate how liberation in prison theatre can be conceived as an embodied movement towards personal and social renewal, an approach that deepens our understanding of its oft-cited humanising potential.

\section{Pragmatist Aesthetics and Liberation in Prison Theatre}

\subsection{Pragmatist Aesthetics and Liberation}

In Art as Experience, John Dewey (1934) proposed a wholly new, egalitarian orientation for aesthetic theory that challenged Immanuel Kant's notion of the aesthetic in art as an abstract rarefied ideal of beauty or the sublime that could only be apprehended by an educated eye (Winston 2006). Crucially, Dewey set out a theory that centred aesthetic experience over aesthetic judgement, collapsing the boundary between the artwork and its maker, and emphasising the importance of the process of creation as equal to the product in its potential to elicit an aesthetic response. He also extended the possibility of aesthetic experience to include every day or "ordinary" experiences, where we might achieve a heightened affective state through our interactions, not only with works of art, but in our relations with the world at large. In this, Dewey extended on his earlier work in philosophy, psychology and educational reform-situated in the tradition of American Pragmatism-giving rise to what Shusterman (2000) subsequently labelled Pragmatist Aesthetics ${ }^{1}$.

Dewey's (1934) aesthetic theory proposes that experience in all of life has potentially aesthetic qualities, and that aesthetic experience in both life and art is a rhythmic process of interactive, culturally determined meaning-making that integrates cognition, imagination, emotion and action as they move towards qualitative unity. Experience itself does not necessarily move us towards the aesthetic. To do this, it must be an experience. For Dewey, experience is both a doing and an undergoing, but for it to be characterised as an experience, it must "run its course to fulfilment" (p. 36). Such experiences, Dewey suggests, do not merely end, but are "consummatory": they are rounded out to become suffused with meaning that leads to new insights. Crucially, a pragmatist aesthetic view argues that experience is not "hidden in the head" (Crippen 2019, p. 92), but is an embodied social and 
cultural process. This approach is especially useful in analysing prison theatre (or other forms of applied theatre), situated as they are between the fictional or symbolic artistic practices of theatre, the "reality" of people's lived experiences and life stories, and the surrounding structural, political and cultural movements.

Far from being a discrete, fenced off and homogenous whole, scholars such as Shusterman (2000) assert that Dewey's (1934) idea of qualitative unity is changeable, diverse and capable of plurality in its composition (see also Alexander 1998; Granger 2001). This gives it credence today in light of post-truth fragmentation and multi-vocal subjectivities. Shusterman (2000, p. 32) suggests, "For Dewey, the permanence of experienced unity is not only impossible, it is aesthetically undesirable; for art requires the challenge of tension and disruptive novelty and the rhythmic struggle of achievement and breakdown of order". It is this dynamic unity that gives an experience its aesthetic quality and characterises the artistic process as merely one form of aesthetic experience, where others might be found in everyday sensory situations such as witnessing a storm, eating a meal or participating in a sporting match. Importantly, Dewey saw "beauty" as "an obstructive term" (p. 135), recognising that aesthetic experience could equally be derived from tension, pain, ugliness and disharmony.

For Dewey (1934), aesthetic experience is made meaningful through what he calls aesthetic emotion - an integration of cognition, imagination and emotion that precipitates aesthetic experience. As such, it is neither wholly intellectual, nor wholly sensory or affective, but an (arguably rare) integration of these into a heightened quality of feeling that leads to new insights. Additionally, significant in Dewey's theory is the idea that the artistic process and the art product exemplify the on-going interaction between organism and environment: the two are inseparable. Subject and object, self and world, process and product, ends and means are, therefore, integrated in their flow towards unity. Within this integrative process, David Granger (2001) suggests, lies the potential for personal and cultural renewal through aesthetic experience-a significant aspect of Dewey's pragmatism.

Following Dewey, both Johnson (2007) and Shusterman (2000, 2008, 2012) recognise that aesthetic experience, personal renewal and cultural renewal are processes that are dependent upon the dynamic interplay between body, mind and culture. Both aestheticians wish to avoid the usual distinction between body and mind in the apprehension of meaning, with Johnson suggesting, "Philosophy needs a visceral connection to lived experience" (p. 262). Shusterman (2012, p. 7) uses the Greek word "soma" to signify "the living, sentient, purposive, perceptive intelligent body through which one perceives the world". $\mathrm{He}$, therefore, conceives somaesthetics as an interdisciplinary program that "concerns the body as the locus of sensory aesthetic appreciation (aisthesis) and creative self-fashioning" (Shusterman 2006, p. 2).

There is a clear connection between pragmatist aesthetics and the philosophies, pedagogies and politics of liberation. In tracing the politics of liberation from Paulo Freire, Lankshear and McLaren (2002) suggest that liberation from oppression remains a constant human preoccupation, regardless of the various context-specific ways it may be conceptualised at different moments in history. Nevertheless, they describe it as a consistent "ontological quest" to "live more humanly and more fully" (p. 1). This is also reflected in the liberatory politics of bell hooks (2000), who emphasises our shared responsibility in ensuring that all members of the community are able to transcend conditions of oppression and domination in order to live "fully and well" (p. 87). This ontological quest is clearly reflected in pragmatist aesthetics. Embodied aesthetic experience, as formulated by Dewey, has an ethical dimension, dependent upon our relations with others as we cultivate ourselves and our worlds towards meaningful forms of renewal. In this way, pragmatist aesthetics frames aesthetic experience as inseparable from ethics, education and political action. 
As two of the most influential theorists in contemporary education, the philosophies of Dewey (1934) and Freire (1996) have often been compared and contrasted in terms of their focus on transformative experience (Harris 2017; Rocha 2018; Strong 2018). Thomas Keans (1999, p. 19) sees strong parallels between their approaches:

Dewey and Freire, who both label themselves progressives, share the scorn for philosophies of education that rely on mechanistic, static, industrial or elitist metaphors. Instead, they build their philosophies around core concepts of experience, growth, inquiry, communication, mediation, problem posing/solving, consciousness-raising, ethical social action and transformation.

Despite these similarities, Keans suggests that a key difference in their approaches is that where Dewey extolled the virtues of transformative experience in supporting an engaged and active citizenry, Freire adopted a more radical stance, seeing it as a precursor to structural revolution.

A pragmatist aesthetic approach to liberation acknowledges the power of transformative aesthetic experience through which people anywhere (not just artists or intellectuals) might acquire an embodied sense of empowerment and agency, which is then directed towards active self-and-world making. Contemporary pragmatist aesthetic theorists have begun to explore the radical potential of such heightened experience, interrogating the embodied "somaesthetic" qualities of, for example, protest and revolution (Crippen 2019; Martin 2019). This approach also moves the study of aesthetics toward a decolonial stance (Deere 2020; Demerson 2020), with an emphasis on relationality and embodied knowledges over individualism and objectivity. Pragmatist aesthetics foregrounds the "art of living"- the embodied, relational act of making selves, worlds and cultures; introduced as an aesthetic theory by Dewey in 1934 but known by Eastern philosophers and Indigenous peoples for millennia.

\subsection{Pragmatist Aesthetics in Prison Theatre}

In the end, works of art are the only media of complete and unhindered communication between man and man [sic] that can occur in a world full of gulfs and walls that limit community of experience. (Dewey 1934, p. 109)

At the beginning of the last decade, applied theatre enjoyed an "aesthetic turn" (Haseman and Winston 2010), as signalled by James Thompson's (2009) influential work Performance Affects: Applied Theatre and the End of Effect, which shifted focus away from the social utility of the work (for example, in education or community building) and toward its affective and aesthetic qualities (White 2015). Within this, there is an acknowledgement that the instrumentalism of applied theatre is inherently bound together with its aesthetic power. As I have suggested elsewhere, aesthetics in applied theatre,

Encompasses the embodied aesthetic engagement and meaning making that occurs within the process of ensemble building and creating works; the resulting works as they are experienced in a community-based event; and the radical potential of such affective encounters to embody ethical participation and social justice. (Woodland 2019a, p. 43)

Contemporary applied theatre continues to engage with its transformative and liberatory origins, focusing on the aesthetics and pedagogies of hope (Baxter 2013), care (Thompson 2015), love (Woodland 2018) and utopia (Busby 2015) -all ideals contained within Freire's critical pedagogy (Keans 1999, p. 23). Yet, despite this turn, there has been little examination of aesthetics or aesthetic engagement in prison theatre scholarship, which, as mentioned above, has most often focused on what the works contribute either to critical cultural theories, or their role in rehabilitating and reforming individuals.

I believe that there is unique potential in exploring the aesthetic within prison theatre, where aesthetic engagement and experience are informed by their situation within an oftenalienating institutional space. Elsewhere I have discussed how the tensions between the institutional context and the moments of freedom, beauty or transcendence that occur in the 
drama space become integral to the aesthetic (Woodland 2013, 2016). Further, a liberatory approach to an aesthetics of prison theatre positions aesthetic experience as a vital aspect of human (and non-human) flourishing. To limit or deny access to aesthetic experience within an institutional context can be described as "aesthetic injustice" (Dalaqua 2020), a coercive tactic that breaks down people's capacities for agentic, transformative self-and-world making.

In thinking through the potential for an aesthetics of liberation, I draw on several prison theatre projects and programs that I have been involved with over the past two decades. From 2001-2004, I was a member of UK's Geese Theatre Company, known for its innovative drama-based approaches to offender rehabilitation that incorporate the use of the mask as a central metaphor-the "front" that we all present to the outside world (and to ourselves) in order to navigate, or survive, a range of life experiences (Baim et al. 2002). Later, after returning to Australia in 2004, I began delivering drama and performance programs in Brisbane Women's Correctional Centre (BWCC). The first, Living Stories, was a twelve-week drama program that drew from a range of drama approaches and strategies including text-based work, improvisation games and drama skills development. Living Stories culminated in a devised performance showing for peers and staff about inspiring women from history (Woodland 2013, 2016).

I delivered several subsequent programs in BWCC, building on the relationships and knowledge that I had developed in Living Stories and forming crucial collaborations with First Nations artists and scholars. Daughters of the Floating Brothel (2012-2015) was a participatory audio drama that explored the experience of female incarceration through the lens of history (Woodland 2020). This was a collaboration with writer Shaun Charles, performance maker Daniele Constance and the women at BWCC. We also consulted with Gunggari Aboriginal Elder and memoirist Aunty Ruth Hegarty on certain aspects of the story. Two years later, in 2017, we worked more closely with Ruth Hegarty on the project Our Ancestors, Our History, Our Lost Culture, a theatre adaptation of her memoir Is that You, Ruthie? (Hegarty 1999), which describes her experiences as a member of the Stolen Generations (Woodland 2019a) ${ }^{2}$. This was produced in collaboration with women at BWCC and First Nations actor Amber Romeril-Sansbury.

Building on these engagements in 2019, at the request of First Nations women incarcerated at BWCC, I worked on Listening to Country, a sound-based creative process and resulting immersive audio work that was aimed at facilitating stress relief, relaxation and cultural connection (Woodland et al. 2019). This was a cross-cultural collaboration between First Nations and non-Indigenous artist-scholars, First Nations Elders and the women at BWCC.

Later in 2019, I was involved in Ngā Pātū Kōrero: Walls That Talk, a documentary theatre production staged by incarcerated men at Unit 8 Te Piriti, a specialist therapy unit for those convicted of sex offences housed within Auckland Prison, Aotearoa New Zealand. The theatre work was directed by Rand Hazou in collaboration with mask practitioner Pedro Ilgenfritz and playwright Stuart Hoar. The work was built around Te Whare Tapa Whā (The House of Four Sides) - a widely used model of Māori health, and also included a work-in-progress documentary podcast episode that I recorded and part-produced (Hazou et al. 2021).

The last four projects were intentionally responsive to the over-incarceration of First Nations peoples in settler colonial nations such as Australia and Aotearoa New Zealand, and were focused on creating cross-cultural aesthetic spaces for truth-telling and collective healing.

This brief overview does not capture the depth and complexity of these projects. Nevertheless, there are some common threads emerging across this work that can be drawn together to explore the potential for and limits of a liberatory aesthetic. In using the theoretical frame I have outlined above, I now turn to examine how theatre operates in terms of liberating the mind and body within a prison setting, the importance of embodiment and relationality in enacting personal and social renewal and the potential for this to 
transform the social structures and institutions that drive mass incarceration. I apply this analysis, not only to "prisoners", but also others who participate, witness or experience these works-such as facilitators, artists, prison staff and the performers' peers and family members, as well as incarcerated or public audiences. The aesthetics of liberation has the potential to act on us all in a communal sense. Indeed, it must, in order to do its wider work in the world.

\section{Prison Theatre and an Embodied Aesthetics of Liberation}

\subsection{Acts of Escape}

Perhaps the most obvious starting point to explore an aesthetics of liberation in prison theatre is its potential as an imaginative act to transport us to worlds outside the prison walls - to figuratively escape. I would suggest that this signifies the kind of imaginative freedom to which Lucas (2020, p. 39) alludes and which, in and of itself, does not constitute liberation. However, while it may sound trite, I have heard over and over again that the prospect of imaginative escape is particularly valuable for incarcerated artists, who have described how being in the theatre workshop space enables them to forget, at least for a while, that they are in prison. Moreover, the theatre and performance practices that occur in a prison theatre workshop arguably provide a much more meaningful and potentially transformative form of figurative escape than one would achieve by watching a movie or reading a book, for example.

The general atmosphere of a typical theatre workshop space is often wholly different from elsewhere in the prison. At its best this is joyous, playful, supportive, spontaneous, respectful and egalitarian. The stark contrast between these qualities and the prison regime-often mind numbing, if not aggressive and violent-is, as described above, integral to the aesthetic in prison theatre. Within a theatre workshop space, the creative process has the potential to focus the mind and body away from the regular prison routine and into other roles, stories, worlds and emotions. In sound or audio-based projects, this includes being transported through listening into the "theatre of the mind" or into the nurturing soundscapes of Country ${ }^{3}$ and belonging. Here, the notion of escape is only the first step in a much more complex and powerful process of engagement-one that has deeper implications for an aesthetics of liberation, which I will discuss further.

Yet, there is no neat binary between the nurturing space of the theatre workshop, and the punitive machinery of the prison outside. The space is permeable and, as outlined below, entrenched roles, conflicts and even joys from outside can be drawn into the creative process and, likewise, resonances from the theatre workshop can make their way into the rest of the prison and beyond. This complicates the potential for liberation through prison theatre practice. However, it also reflects the pragmatist aesthetic view of self-and-world making that defies value judgement, but rather draws all elements-positive, negative or otherwise-into the flow of experience. It is, therefore, important to move beyond the figurative idea of "escape" and examine more deeply how this might progress toward genuine ideals of liberation.

\subsection{Acts of Unbinding}

Dewey's (1934) aesthetic theory came later in his career, an extension of his ongoing philosophical reckoning with-among other concerns of the time-the industrial revolution and rise of fascism. In commenting on the institutionalisation and "compartmentalisation" of modern society, Dewey observed, "In much of our experience our different senses do not unite to tell a common and enlarged story .... Prestige goes to those who use their minds without participation of the body and who act vicariously through control of the bodies and labor of others" (21). In Thomas Alexander's (1998) view, Dewey's aesthetic theory posits that art "points the way for the liberation of the sensuous human body from its institutionalized alienation" (13). One could argue that contemporary society reflects a similar tendency toward unresolved sensory input and disembodied alienation to that which Dewey observed, albeit with more complexities arising from the pervasive 
technologies of mass communication and social media. Further, contemporary carceral logics serve to render larger numbers of people than ever before, not just figuratively, but literally institutionalised through regimes of surveillance, over-policing and incarceration. In this context, the liberatory aesthetic potential of prison theatre can be viewed in both personal and political terms.

There exist numerous descriptions of the rigid, internalised codes of survival that people develop in response to the coercive regimes of the carceral state; the seminal works of Michel Foucault ([1975] 1991) and Erving Goffman ([1961] 2017) have greatly influenced prison theatre scholarship in this area. Embodied responses to trauma, violence and carcerality have sometimes been cultivated for years prior to actual imprisonment. Describing the "dysfunctional culture" within Australian women's prisons two decades ago, Patricia Easteal (2001, p. 87) suggested women were encouraged to adopt the survival strategies that they had learned growing up in abusive and dysfunctional homes: "Don't talk, don't trust and don't feel". I witnessed this more recently, with the women at BWCC variously describing themselves as robotic, numb, "boxing things up" and "running on bare minimum" while navigating the prison environment (Woodland 2016). Geese Theatre Company's signature "Fragment Masks" represents eight different coping behaviours that exist as fragments within the overarching "mask" of survival that people wear in prison and outside (Baim et al. 2002, pp. 184-85). One of these masks, the "brick wall", directly echoes these descriptions of numbness and mistrust.

One of the women I worked with in the Living Stories project used a vivid description for this form of coping: the "bound-up prison person." In the same project, I found that the women habitually storied their life in prison as either an adversarial "game", or else a life on hold-what one woman called "Groundhog Day", and another called "a momentary lapse of reality." The bound-up prison person was a role that enabled the women to navigate their way through these narratives. In that study, and the projects I have facilitated since, I have found that participation in drama enables a certain level of "unbinding" to occur, where incarcerated artists might become unbound from their usual roles and coping behaviours, but also from the adversarial narratives of the prison, and the often tragic life stories that they are required to repeat over and over within the bureaucracies of crime, punishment and social services. In Ngā Pātū Kōrero: Walls That Talk, the performance (which incorporated mask and physical theatre) facilitated a sense of "re-embodiment" for the men who were living within a system and space that routinely polices Māori male bodies (Hazou et al. 2021). Looking through a pragmatist aesthetic lens that draws from somaesthetics (Shusterman 2008), this unbinding or re-embodiment is able to occur through the somatic practices of theatre and performance, driven by the embodied elements of emotion, spontaneity and role.

Theatre games, improvisation, rehearsal and devising processes all demand actors to respond spontaneously, sometimes playfully, to situations as they arise. In this process, embodied habits are reworked via spontaneity toward innovation in response to the unfolding experience (see O'Neill 1995, pp. 79-80). Through this, incarcerated actors are invited to both experience and represent through performance a range of emotions that move beyond the "brick wall", and to allow emotion to act as a searchlight in making aesthetic decisions and judgements. For one participant in Living Stories, the expression of emotion was important in her process of unbinding. She observed that the drama invited her to express emotion beyond the binaries of "happy and angry," and that this included both fictional representations of emotion as well as her actual emotional states within the theatre group. When I asked her why this was important, she replied, "It reminds me I am human. I'm not prison property like they carry on" (Woodland 2013, p. 84).

In prison theatre, incarcerated artists have an opportunity to "expand their role repertoire" (Baim et al. 2002, p. 21), playing roles other than those of "criminal" or "drug addict". Again, this encompasses both the fictional roles that they may perform in a play, but also those agentic roles that emerge through the creative process such as actor, educator, artist, collaborator and critical thinker. Viewed through the lens of liberatory pedagogy, 
this repertoire potentially shifts incarcerated actors from their position as objects-of scrutiny, of surveillance, of rehabilitative interventions-to subjects, engaging in the kinds of critical, reflective and spontaneous embodied practices that are necessary to produce a performance.

Of course, this kind of expansion does not always occur through prison theatre, nor does it necessarily result in uncomplicated positive experiences for actors. In many cases, there is a tension between the coercive culture of the prison and the habits formed over a lifetime, and this new repertoire, which sometimes results in conflict. In the case of Living Stories, I have described how the workshop is a permeable space, not always able to be insulated from the conflicts and tensions occurring in the rest of the prison (Woodland 2016). Conversely, the embodied habits and roles occupied in the surrounding spaces of the prison are not always dysfunctional or negative, with many women, for example, describing how they express and experience inside a strong sense of supportiveness and sisterhoodeven safety and security-that they do not experience outside. The key to the aesthetic in prison theatre (as with any aesthetic experience) is that the process does not march unhindered toward "beauty", goodness or redemption, but also recognises the ugly, the painful and the "fragmented and discordant" (Shusterman 2008, p. 87). The aesthetic in prison theatre resides in the tension between disturbance and harmony-as equally necessary in self-and-world creation (Dewey 1934, p. 17).

Nevertheless, when renewed roles and ways of being are embodied through prison theatre, I have found that a crucial aspect of this expansion is the opportunity to demonstrate this to friends and family through a live or recorded performance outcome; and for this expansion to be witnessed by trusted peers and staff in the institution to help re-set relationships and challenge preconceptions. Paradoxically, prison theatre actors invariably also talk about how theatre enables them to be themselves-to reconnect with the roles and identities that have been "stripped" (Goffman [1961] 2017) from them through the incarceration process-and for these to be unbound through meaningful artistic engagement. In Daughters of the Floating Brothel, one woman described how she was showing a completely different side of herself through the theatre process, one that she wanted to share with her son (Woodland 2019b). As one Living Stories participant put it when asked what she thought of the drama program, "I love it! It's where the best of me comes out".

The acts of unbinding described thus far have been largely related to how incarcerated actors might liberate themselves from rigid carceral roles and identities, how they might recover a sense of embodiment within a somatically controlling regime that promotes "docile bodies" (Foucault [1975] 1991), and to some degree, how this may reverberate into their relationships with others. Without an extensive longitudinal study, it is impossible to know the extent to which this reverberation might occur, and even then, it would be impossible to attribute this to any one set of experiences. Yet, there is, as discussed earlier, the potential to transform adversarial prison narratives and relationships through creative practice, which might, in turn, impact on the culture of the institution. This might conceivably impact relationships with family and the community outside the boundaries of the prison, the implications of which I explore further below.

Creative practice can also act upon the institution in less visible yet "unbinding" ways, imbuing the space with spontaneous sounds and energies. In the audio drama and soundscape projects that I described earlier, this included refiguring the coercive contemporary soundscapes of the prison through imaginative re-sounding. This involved, for example, creating Foley effects with found objects, producing haunting vocal soundscapes to create the atmosphere of a gothic prison and recording bare footsteps and heartbeats to evoke the human connection to natural environments and Country. These organic "human" sounds worked against the industrial sounds of air conditioners, electronic buzzers and slamming doors, providing the artists with at least fleeting opportunities for acoustic or sonic agency (LaBelle 2020; Rice 2016). 


\subsection{Acts of Love}

In the previous section, I emphasised the potential for personal expansion and liberation through prison theatre and described how this might begin to influence relationships with others, and wider cultures and energies within the institution. A pragmatist aesthetic frame acknowledges the importance of self-care and self-creation as necessary in order to enable people to move toward social and cultural liberation and renewal (Shusterman 2000). Practices such as theatre that engage both body and mind in an aesthetic - somaestheticprocess are particularly powerful in facilitating self-creation and agency. This approach also acknowledges the embodied relational dimension of all aesthetic experience-artistic and otherwise-and that all artistic practices are expressions of how we relate to each other and the world at large, what pragmatist aestheticians describe as an "art of living" (Shusterman 2000). It is this quality of relationality that I turn to now as crucial to an aesthetics of liberation in prison theatre.

The connection between relationality and liberation is perhaps best articulated by bell hooks through her writings on the role of love in liberatory politics as influenced by Martin Luther King Jr. and Paulo Freire, among others (hooks 1993, 2000; Monahan 2011). In Pedagogy of the Oppressed, Freire (1996, p. 45) suggests that the fight for liberation "constitute[s] an act of love opposing the lovelessness which lies at the heart of the oppressors' violence." hooks extends this idea, describing love as a deliberate and reciprocal practice rather than a feeling, one that requires nurturing and sustained commitment in order to enact just relations with others (Monahan 2011, p. 106). She frames this as an "ethic of love" that must underpin all actions towards social justice and transformation (hooks 2000). Here, there is an emphasis on responsibility and accountability, and a demand for criticality turned inwards and outwards, as we engage in an "ongoing practice of bettering oneself and others" (Monahan 2011, p. 107). Drawing from the teaching of Martin Luther King Jr., hooks presents the ideal of the "beloved community" as the context in which oppression and domination are no longer present and where harmony prevails. Crucially, this vision of the harmonious beloved community affirms difference and is able to hold conflict and difference; it does not promote uniformity or normativity. As Michael Monahan (p. 109) suggests, "The ideal of the beloved community does not demand that we take up our role in the community purged of all our cultural and historical particularity" (Monahan 2011, p. 109). As such, it can be seen to reflect the quality of dynamic unity that is present in Dewey's (1934) aesthetic theory.

Elsewhere I have described how the theatre ensemble might represent, or even become, such a beloved community, where the ethic of love enables the group to grow in creativity and solidarity (Woodland 2018). Theatre exemplifies relationality within artistic practice, generated by an ensemble of individuals - with a diversity of experiences and standpoints-who must work collaboratively toward the shared goal of an aesthetically engaging performance outcome. In most prison theatre practices, drawn as they are from applied or community engaged approaches to theatre, as discussed earlier, considerable effort is made by ensemble leaders (or facilitators) to cultivate a safe, trusting and respectful space where creativity can flourish. The collaborative and spontaneous acts of improvisation often involved in prison theatre require a commitment from all the members to surrender to the creative process and trust and nurture each other in an environment that commonly promotes hypervigilance and mistrust. This is an act of love.

While the ensemble might be working towards a performance goal, in prison theatre (as with all applied theatre), equal weight is given to the process of creation-what happens in the workshop space as the group progressively develops the trust, imaginative capacities, performance skills and confidence to make the show. This reflects a pragmatist and liberatory aesthetic, where self-and-world making is a process rather than an outcome; a process that will inevitably cycle through successes and failures, encouragements and setbacks, as it nevertheless moves towards the ideals of justice and renewal. 
As I have discussed earlier, there are limits to the potential for the operation of beloved community in prison theatre to insulate its members from oppression and domination. When it is working well, the beloved community is key to the personal unbinding I have described above, where not only is "the best of me" able to come out, but where I am accepted and affirmed by others in the ensemble. However, this may not be possible elsewhere in the prison, in which case the "brick wall" as a coping mechanism must be reinstated in order to survive the regular routine. Further, there is a risk that oppressive power dynamics can be replicated in prison theatre practices where artists entering from outside might (sometimes unconsciously) impose their own values within the space, or where incarcerated actors might use the workshop to progress their own position within the prison hierarchy. Finally, many of the projects I have described have taken place over a very short period of time (two-to-twelve weeks), with ensemble numbers fluctuating dramatically over the course of the workshop program due to the competing demands of work, health checks, legal visits or the release or movement of prisoners to other facilities due to short sentences. I would suggest that the most successful projects that achieve this sense of beloved community are those that, paradoxically, involve people who are incarcerated for life, or at least long-term sentences. This enables them to make a longterm commitment, and work over time to create a set of shared values and expectations (embracing the diversity of the group) that ultimately facilitates deeper engagement and expansion. Ideally, this also results in the kind of autonomy that can be seen in prison theatre companies that are led by incarcerated actors themselves ${ }^{4}$.

Regardless of the themes or content of the play, the prison theatre workshop as a beloved community has the potential to break down the inevitable prison hierarchies and often racialised divisions that can exist elsewhere in the institution. In the ideal prison workshop space, the qualities of love and nurturing are directed not only towards others in the group, but also the artwork itself - the shared endeavour of the show-which is itself a loving gift for the audience. In all of the projects I have encountered, there is a consistent desire on the part of everyone involved, not only to put on the show itself, but to communicate to the audience some of the enjoyment that they have experienced and insights they have gained in making it. In longer term projects, this can precipitate a drive to enrol others into the ensemble and become teachers or mentors to them so that they can benefit from the same experiences, and then to continue their creative practice and teaching in the community once they have left prison ${ }^{5}$. This can be seen to echo the kind of "love-in-action" described by hooks (2000) that has the potential to be systemically or politically transformative.

\subsection{Acts of Liberation}

There is no real way of knowing whether prison theatre practices can or do translate from those acts of "unbinding", relationality and love that I discussed above into the level of political agency that might bring about wider systemic change. At the very least, following Boal (1985), we can hope that they will prepare incarcerated actors to take on more agentic roles within their communities. As Baz Kershaw (2004, p. 49) suggests,

Drama can significantly contribute to the collective and individual creation of autonomous subjects, especially through an engagement with systems of formalized power in an effort to create radical freedom. Such freedom can be achieved through actions which combine resistant and transcendent ideological dynamics, which oppose dominant ideologies and also at least gesture to possibilities beyond them.

In the previous sections, I have, therefore, attempted to build a picture of how prison theatre, at its best, can engage incarcerated artists in the kinds of self-and-world making that might gesture toward liberation in the political sense. As I have indicated earlier, much has been written about the pedagogies of possibility, hope and utopia that underpin applied theatre- - how it enables groups to imagine and (sometimes) realise possible selves, possible worlds and performed utopias. Further, the egalitarian creative process in applied 
theatre engages the ensemble in a process of collective interpretive inquiry into the themes being depicted in the performance, whether these are devised by the group themselves, or contained in the works of a canonical playwright such as Shakespeare. Boal (1985) likened this embodied process - through group discussion, symbolisation and performance making-to Freire's (1996, p. 104) notion of "conscientization" or critical thinking about the world-a process that hooks (1993, p. 147) describes as the "decolonization of the mind."

This feature was evident in the projects Daughters of the Floating Brothel (2015) and Our Ancestors, Our History, Our Lost Culture (2017). Here, the women expressed how they valued the opportunity to engage with the historical content of the plays in an educational sense and expressed a strong desire to educate audiences about the treatment of First Nations peoples in colonial and Federation era Australia. They described a sense of pride that they were able to share their culture in this way. These two projects reflected an aesthetics of truth-telling, where First Nations and non-Indigenous women (including the creative team visiting from outside) were able to create a space of intimacy and trust through which they could explore the difficult truths of intergenerational colonial trauma and violence that continue to reverberate into the present (Woodland 2019a, 2020). This reflects the emphasis on truthfulness with ourselves and others that, in hooks' view, characterises the ethic of

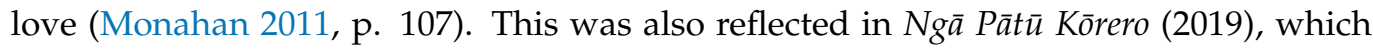
opened up a relational space in which the ensemble members were able to transcend the stigmas associated with sexual offending, acknowledge certain truths and create a space for collective healing "that might contribute to a sense of restoration or balance" between the performers and the broader community (Hazou et al. 2021). Prison theatre performances not only provide an opportunity for audiences to see incarcerated actors in a different light, as described earlier, but they enable a restoration of beloved community that (if only momentarily) has the potential to reach beyond the prison walls.

Both hooks (2000) and Freire (1996) emphasise the importance in recognising the subjective personhood of those who are oppressed in order to properly realise a praxis of liberation. Prison theatre performances can enable this to occur, as discussed above, both within the creative workshop space, and the space of witnessing and restoration that can be created when an audience is invited to share in the performance. This pragmatist liberatory aesthetic approach suggests that if people are "bound up" in embodied roles such as prisoner, criminal or drug dealer, and bound up in oppressive carceral relationships and narratives that perpetuate these roles, then they will be unlikely to fully imagine themselves outside the carceral system, much less imagine other systems all together.

It is worth noting that the projects I describe here that foregrounded the experiences of First Nations peoples in carceral settings reflected a deeper form of relationality-a relational ontology - that is at the heart of Indigenous ways of being and knowing (Martin and Mirraboopa 2003). This centres relationships and interconnectedness with family, community and the natural world, and the ensuing accountabilities and obligations, that enable all to flourish together. While it is not my intention to conflate this with a pragmatist aesthetic or liberatory system, a relational ontology resides at the core of the philosophies for transformative experience in the work of Dewey (1934), Freire (1996) and hooks (2000) that I cite. This approach progresses a decolonial aesthetics in prison theatre that moves away from notions of individual responsibility contained in neoliberal approaches to crime and justice, and toward liberating the senses from prevailing structures of racial inequality and mass incarceration.

\section{Conclusions}

A more traditional approach to arts in prisons would see its humanising potential as a process of making criminals into better humans-into, cynically speaking, more compliant citizens-through the development of "soft skills" and exposure to culture and creativity. Yet, as I have hopefully demonstrated, there is a far more complex process of self-andworld making at play here. Theatre in prison has the potential to facilitate a unique form of transformative aesthetic experience and creative agency, providing artists with alternative 
self-images to those of "prisoner" or "criminal", empowering them to reconfigure their place in the family, community and wider society. At its best, theatre practice can transmute rigid, internalised codes of survival that have been cultivated in response to traumatic life experiences outside, and the prison's volatile and coercive regimes inside, enabling an expression of full humanity. This is further heightened when audiences are able to witness these expressive acts, as it creates a restorative space of shared understanding and community healing. Drawing from pragmatist aesthetics and liberatory pedagogies and politics, liberation in prison theatre can, therefore, be conceived as an embodied movement toward personal and social renewal; an approach that deepens our understanding of its oft-cited humanising potential, and its limits.

The projects I have discussed here have largely taken place inside prisons, and therefore, I have focused on the liberatory potential within an institutional space. However, it is not such a great leap to imagine how this aesthetics might be deployed to promote liberation from the wider carceral systems or "webs" (Anthony 2020) in which the prison building exists as just one constituent part. Thinking hopefully and idealistically, an embodied aesthetics of liberation might, therefore, be deployed both within and beyond the prison walls to in order to "rehabilitate" —or dismantle completely—the oppressive systems and policies that drive institutionalised alienation and mass incarceration. Imaginative freedom can certainly liberate our minds and transport us beyond the prison wall. However, this represents only the first threshold in imagining alternative worlds altogether-worlds that do not rely on punitive approaches to crime and justice, and instead create still more beloved communities. In these communities, we might collectively take responsibility for healing the harms associated with colonisation, systemic marginalisation and trauma that ultimately affect us all.

Funding: The projects discussed in this paper received research and arts funding from a range of sources (grant numbers n/a): Australia Council for the Arts, Arts Queensland, Creative New Zealand, Australian Academy of the Humanities, Lowitja Institute for Aboriginal and Torres Strait Islander Health Research.

Institutional Review Board Statement: This paper is based on research that was conducted between 2011-2019 and no new data were collected for this study. All of the prior research discussed in this paper was conducted according to the guidelines of the Declaration of Helsinki, and approved by the Human Research Ethics Committees of the respective institutions in which projects were undertaken (Griffith University, Australia; Massey University, New Zealand).

Informed Consent Statement: Informed consent was obtained from all subjects involved in the prior research studies informing this paper.

Data Availability Statement: No new data were created or analysed in this study. Data sharing is not applicable to this article.

Acknowledgments: The research discussed in this paper was completed with support from Griffith University, Brisbane (School of Education and Professional Studies, Queensland Conservatorium Research Centre); Massey University, Auckland (School of Humanities, Media and Creative Communication); and University of Melbourne (Faculty of Fine Arts and Music). Some of the research discussed in this paper was completed with support from Queensland Corrective Services. The views expressed herein are solely those of the author and in no way reflect the views or policies of Queensland Corrective Services. I would like to acknowledge all of the artists and scholars (both incarcerated and not) who were involved in the projects described here, whose collective creativity, knowledge and insights have contributed greatly to my ongoing thinking and reflections.

Conflicts of Interest: The author declares no conflict of interest.

\section{Notes}

1 It is beyond the scope of this paper to fully explore the different ways in which Pragmatist Aesthetics departs from other strands of aesthetics as a discipline; however, I attempt here to draw out the key features that are germane to my discussion of liberation in prison theatre. 
2 The term Stolen Generations came out of the landmark report Bringing them home: Report of the National Inquiry into the Separation of Aboriginal and Torres Strait Islander Children from their Families (Wilson 1997), which detailed the extent and impacts of government policies of forced removal that were carried in Australia throughout the early nineteenth century up until the 1970s.

3 Country is an essential ontological concept for many Indigenous Australian Peoples, and it aids in sharing their relationship to land, place and a sense of belonging (Carlson 2016).

4 See for example William Head on Stage (WHoS), the longest running prison theatre company in Canada, led by a board of incarcerated men who invite outside artists to collaborate on an annual production (Prendergast 2016).

5 These ideas were recently discussed at length by a panel of "returned citizens": formerly incarcerated actors from three different prison theatre projects in Australia and the USA, who spoke at the fourth annual Shakespeare in Prisons Conference 2020-2021, hosted by the University of Notre Dame, USA.

\section{References}

Alexander, Thomas M. 1998. The art of life. In Reading Dewey: Interpretations for a Postmodern Generation. Edited by Larry A. Hickman. Bloomington: Indiana University Press, pp. 1-22.

Anthony, Thalia. 2020. Settler-colonial governmentality: The carceral webs woven by law and politics. In Questioning Indigenous-Settler Relations. Edited by Sarah Maddison and Sana Nakata. Singapore: Springer, pp. 33-53.

Baim, Clark, Sally Brookes, and Alun Mountford. 2002. The Geese Theatre Handbook: Drama with Offenders and People at Risk. Winchester: Waterside Press.

Balfour, Michael, ed. 2004. Theatre in Prison: Theory and Practice. London: Intellect Books.

Baxter, Veronica. 2013. Postcards on the aesthetic of hope in applied theatre. Matatu 44: 257-93. [CrossRef]

Billone, Nina. 2009. Performing civil death: The Medea Project and theater for incarcerated women. Text and Performance Quarterly 29: 260-75. [CrossRef]

Boal, Augusto. 1985. Theatre of the Oppressed. Translated by A. Charles, and Maria-Odilia Leal McBride. New York: Theatre Communications Group.

Busby, Selina. 2015. A pedagogy of utopia. Research in Drama Education: The Journal of Applied Theatre and Performance 20: 413-16. [CrossRef]

Carlson, Bronwyn. 2016. Striking the right chord: Indigenous people and the love of country. AlterNative: An International Journal of Indigenous Peoples 12: 498-512. [CrossRef]

Clark, Maud. 2020. Somebody's Daughter Theatre Company: The arts unapologetically transcendent. In Applied Theatre: Women and the Criminal Justice System. Edited by Caoimhe McAvinchey. London: Bloomsbury Methuen Drama, pp. 163-70.

Crippen, Matthew. 2019. Body politics: Revolt and city celebration. In Bodies in the Streets: The Somaesthetics of City Life. Edited by Richard Shusterman. Boston: Brill, pp. 89-110.

Dalaqua, Gustavo H. 2020. Aesthetic injustice. Journal of Aesthetics and Culture 12: 1712183. [CrossRef]

Davey, Linda, Andrew Day, and Michael Balfour. 2015. Performing desistance: How might theories of desistance from crime help us understand the possibilities of prison theatre? International Journal of Offender Therapy and Comparative Criminology 59: 798-809. [CrossRef]

Deere, Don Thomas. 2020. The spacing of decolonial aesthetics. Journal of World Philosophies 5: 89-98.

Demerson, Rainy. 2020. Sensing the stage: Decolonial readings of African contemporary dance. In African Somaesthetics: Cultures, Feminisms, Politics. Edited by Catherine F. Botha. Boston: Brill, pp. 95-119.

Dewey, John. 1934. Art as Experience. New York: Capricorn.

Easteal, Patricia. 2001. Women in Australian prisons: The cycle of abuse and dysfunctional environments. The Prison Journal 81: 87-112. [CrossRef]

Foucault, Michel. 1991. Discipline and Punish: The Birth of the Prison. Translated by Alan Sheridan. Harmondsworth: Penguin. First published 1975.

Freire, Paulo. 1996. Pedagogy of the Oppressed. revised. New York: Continuum.

Goffman, Erving. 2017. Asylums: Essays on the Social Situation of Mental Patients and Other Inmates. Abingdon and New York: Routledge. First published in 1961.

Granger, David. 2001. Towards an embodied poetics of the self: Personal renewal in Dewey and Cavell. Studies in Philosophy and Education 20: 107-24. [CrossRef]

Harris, Fred. 2017. Dewey's and Freire's popular philosophies of education in a capitalist context. Encounters in Theory and History of Education 18: 100-18. [CrossRef]

Haseman, Brad, and Joe Winston. 2010. 'Why be interested?' Aesthetics, applied theatre and drama education. Research in Drama Education: The Journal of Applied Theatre and Performance 15: 465-75. [CrossRef]

Hazou, Rand, Sarah Woodland, and Pedro Ilgenfritz. 2021. Performing te whare tapa whā: Cultural rights and decolonising corrections. Research in Drama Education: The Journal of Applied Theatre and Performance 26: 494-510. [CrossRef]

Hegarty, Ruth. 1999. Is that You, Ruthie? Brisbane: University of Queensland Press.

Heritage, Paul. 2006. Staging human rights: Securing the boundaries? Hispanic Research Journal 7: 353-63. [CrossRef] 
hooks, bell. 1993. bell hooks speaking about Paulo Freire: The man and his work. In Paulo Freire: A Critical Encounter. Edited by Peter McLaren and Peter Leonard. London and New York: Routledge, pp. 46-54.

hooks, bell. 2000. All About Love: New Visions. New York: William Morrow and Company.

Johnson, Mark. 2007. The Meaning of the Body: Aesthetics of Human Understanding. Chicago: University of Chicago Press.

Keans, Thomas. 1999. Service-learning in two keys: Paulo Freire's critical pedagogy in relation to John Dewey's pragmatism. Michigan Journal of Community Service Learning (Fall) 6: 15-29.

Kershaw, Baz. 2004. Pathologies of hope in drama and theatre. In Theatre in Prison: Theory and Practice. Edited by Michael Balfour. London: Intellect Books, pp. 35-52.

LaBelle, Brandon. 2020. Sonic Agency: Sound and Emergent Forms of Resistance. London: Goldsmiths Press.

Lankshear, Colin, and Peter McLaren, eds. 2002. The Politics of Liberation: Paths from Freire. London and New York: Routledge.

Lucas, Ashley. 2020. Prison Theatre and the Global Crisis of Incarceration. London: Bloomsbury Methuen Drama.

Martin, Karen, and Booran Mirraboopa. 2003. Ways of knowing, being and doing: A theoretical framework and methods for indigenous and indigenist research. Journal of Australian Studies 27: 203-14. [CrossRef]

Martin, Noemi. 2019. Bodies in the streets of Eastern Europe: Rhetorical space and the somaesthetics of revolution. In Bodies in the Streets: Somaesthetics of City Life. Edited by Richard Shusterman. Boston: Brill, pp. 111-29.

McAvinchey, Caoimhe. 2011. Theatre and Prison. Basingstoke: Palgrave Macmillan.

Monahan, Michael J. 2011. Emancipatory affect: Bell hooks on love and liberation. The CLR James Journal 17: 102-11. [CrossRef]

O’Neill, Cecily. 1995. Drama Worlds: Framework for Process Drama. Portsmouth: Heinemann.

O'Toole, John. 1992. The Process of Drama: Negotiating Art and Meaning. London: Routledge.

Pensalfini, Rob. 2016. Prison Shakespeare: For These Deep Shames and Great Indignities. Palgrave Shakespeare Studies. New York: Palgrave Macmillan.

Prendergast, Monica, and Juliana Saxton, eds. 2009. Applied Theatre: International Case Studies and Challenges for Practice. Bristol: Intellect.

Prendergast, Monica. 2016. Tracing the journey to here: Reflections on a prison theatre devised project. Theatre Topics 26: 343-49. [CrossRef]

Rice, Tom. 2016. Sounds inside: Prison, prisoners and acoustical agency. Sound Studies 2: 6-20. [CrossRef]

Rocha, Samuel D. 2018. James' Pragmatism in Dewey and Freire: On the educational need for a view of the universe. Asia Pacific Journal of Educational Research 1: 51-56. [CrossRef]

Shailor, Jonathan, ed. 2011. Performing New Lives. London and Philadelphia: Jessica Kingsley.

Shusterman, Richard. 2000. Pragmatist Aesthetics: Living Beauty, Rethinking Art, 2nd ed. Lanham: Rowman and Littlefield Publishers.

Shusterman, Richard. 2006. Thinking through the body, educating for the humanities: A plea for somaesthetics. Journal of Aesthetic Education 40: 1-21. [CrossRef]

Shusterman, Richard. 2008. Body Consciousness: A Philosophy of Mindfulness and Somaesthetics. Cambridge: Cambridge University Press.

Shusterman, Richard. 2012. Body and the arts: The need for somaesthetics. Diogenes 59: 7-20. [CrossRef]

Strong, Pauline Turner. 2018. John Dewey's philosophy of education in the neoliberal age. In The Experience of Neoliberal Education. Edited by Bonnie Urciuoli. New York and Oxford: Berghahn Books, pp. 17-31.

Thompson, James, ed. 1998. Prison Theatre: Perspectives and Practices. London: Jessica Kingsley Publishers.

Thompson, James. 2009. Performance Affects: Applied Theatre and the End of Effect. Basingstoke: Palgrave Macmillan.

Thompson, James. 2015. Towards an aesthetics of care. Research in Drama Education: The Journal of Applied Theatre and Performance 20: 430-41. [CrossRef]

Wagner, Betty Jane. 1976. Dorothy Heathcote: Drama as a Learning Medium. Washington, DC: National Education Association.

Walsh, Aylwyn. 2019. Prison Cultures: Performance, Resistance, Desire. London: Intellect Books.

White, Gareth, ed. 2015. Applied Theatre: Aesthetics. London: Bloomsbury.

Wilson, Ronald. 1997. Bringing them Home: Report of the National Inquiry into the Separation of Aboriginal and Torres Strait Islander Children from their Families; Sydney: Human Rights and Equal Opportunity Commission. Available online: https://humanrights.gov.au/ our-work/bringing-them-home-report-1997 (accessed on 9 September 2021).

Winston, Joe. 2006. By way of an introduction, some initial reflections on beauty. Research in Drama Education: The Journal of Applied Theatre and Performance 11: 43-45. [CrossRef]

Woodland, Sarah. 2013. Magic mothers and wicked criminals: Exploring narrative and role in a drama programme with women prisoners. Applied Theatre Research 1: 77-89. [CrossRef]

Woodland, Sarah. 2016. The art of living in prison: A pragmatist aesthetic approach to participatory drama with women prisoners. Applied Theatre Research 4: 223-36. [CrossRef]

Woodland, Sarah. 2018. I Love You I Love You: Aesthetics of love in culturally diverse youth theatre ensemble. Youth Theatre Journal 32: 164-76. [CrossRef]

Woodland, Sarah. 2019a. Aesthetics of truth-telling: Intercultural applied theatre praxis in an Australian women's prison. ArtsPraxis 6: 39-57.

Woodland, Sarah. 2019b. 'This place is full of drama queens': Reflecting on the value of drama in a women's prison. In Performing Arts in Prisons: Creative Perspectives. Edited by Michael Balfour, Brydie-Leigh Bartleet, Linda Davey, John Rynne and Haub Schippers. Bristol: Intellect, Ch. 4. 
Woodland, Sarah. 2020. 'Daughters of the Floating Brothel': Engaging Indigenous Australian women in prison through participatory radio drama. In Applied Theatre: Women and Criminal Justice. Edited by Caoimhe McAvinchey. London: Bloomsbury Methuen Drama, pp. 79-104.

Woodland, Sarah, Leah Barclay, Vicki Saunders, and Bianca Beetson. 2019. Listening to Country: Exploring the value of acoustic ecology with Aboriginal and Torres Strait Islander women in prison. Soundscape: The Journal of Acoustic Ecology, World Forum for Acoustic Ecology 17: 41-44. Available online: https://www.wfae.net/uploads/5/9/8/4/59849633/soundscape_vol17.pdf (accessed on 9 September 2021). 